\title{
Effects of phosphorus and potassium bacterial Fertilizer on Rhizosphere soil nutrients and Fruit quality of Huangguo Citrus
} \author{
$\mathrm{Sun}^{2}$, and Bo Xiong ${ }^{1, *}$ \\ ${ }^{1}$ College of Horticulture, Sichuan Agricultural University, 611130 Chengdu, Sichuan, China \\ ${ }^{2}$ Institute of Pomology \& Olericulture, Sichuan Agricultural University, 611130 Chengdu, Sichuan, China
}

Youting Yang ${ }^{1}$,Yan Gong ${ }^{1}$,Zhaofang Chen ${ }^{1}$, Liping Tan ${ }^{1}$, Qing Zhang ${ }^{1}$, Xia Qiu ${ }^{1}$, Honghong Deng ${ }^{1}$, Ling Liao ${ }^{1}$, Guochao

\begin{abstract}
In this experiment, 8-year-old yellow fruit citrus trees were used as materials, and the soil nutrients were determined with the combination of Bacillus megaterium, glial bacillus, organic-inorganic compound fertilizer and organic fertilizer, and the conventional application of organic fertilizer as the control. The results showed that the soil nutrients of the treatments of Bacillus megaterium, Bacillus glia and organic fertilizer were significantly higher than those of the control. The treatment of applying Bacillus megaterium and Bacillus glia alone reached a significant level in many soil nutrient indexes. It is suggested that the combination of Bacillus megaterium, Bacillus glia and organic fertilizer should be applied in production.
\end{abstract}

\section{Introduction}

Huangguo mandarin is a natural hybrid of orange which is unique and rich in resources in Sichuan Province. It originates from Xinmian Town, Shimian County, Sichuan Province. It has the characteristics of extra late maturity, high yield and the same tree of flowers and fruits [2]. However, there are great differences in soil fertility among different Huangguo mandarin planting regions in asbestos area, so it is of great significance to activate soil potential and ensure the sustainable production of Huangguo mandarin with high quality and high efficiency. The research on fertilization of Huangguo mandarin is mainly based on special inorganic fertilizer and organic fertilizer, but biological bacterial fertilizer has not been involved.

Through the determination of the physical and chemical properties of Huangguo citrus rhizosphere soil under the application of biological bacterial fertilizer, this experiment explored the application effect of biological bacterial fertilizer on asbestos Huangguo mandarin, so as to provide a basis for the application and popularization of biological bacterial fertilizer on Huangguo mandarin and other mixed oranges.

\section{Materials and Methods}

\subsection{Experimental materials}

The experimental Huangguo mandarin plants came from Xiaoshui Township, Shimian County, 8 years old, a total of 15 plants, the growth environment and fertilization management conditions were the same, the tree body was strong, the tree potential was basically the same, and there were no obvious diseases and insect pests. The strains were Bacillus giganticus ACCC10011 collected from Guangdong microbial strain Preservation Center and one strain of Bacillus glia CGMCC1.153 collected from China Institute of Microbiology. The bacteria fertilizer can be applied to soil by adsorption of vermiculite. The fertilizer used in conventional fertilization is "Baoshiling" inorganic-organic compound fertilizer. The organic fertilizer used is dried chicken manure. The nutrient content was shown in the following table:

Table 1. Fertilizer nutrient content.

\begin{tabular}{|c|c|c|c|c|}
\hline project & $\begin{array}{c}\text { Organic } \\
\text { matter } \\
(\%)\end{array}$ & $\begin{array}{c}\text { Pure } \\
\text { nitroge } \\
(\%)\end{array}$ & $\begin{array}{c}\text { Phosphorus } \\
\left(\mathrm{P}_{2} \mathrm{O}_{5} \%\right)\end{array}$ & $\begin{array}{c}\text { Potassium } \\
\left(\mathrm{K}_{2} \mathrm{O} \%\right)\end{array}$ \\
\hline $\begin{array}{c}\text { Organic- } \\
\text { inorganic } \\
\text { compound } \\
\text { fertilizer t }\end{array}$ & - & 15 & 9 & 6 \\
\hline $\begin{array}{c}\text { Dried } \\
\text { chicken } \\
\text { manure }\end{array}$ & 25.5 & 1.63 & 1.54 & $0.85 \%$ \\
\hline
\end{tabular}

The experiment was conducted in the orchard of Xiaoshui Township, Anshun Village, Shimian County, Ya'an City, Sichuan Province from April 2015 to March 2016. The experimental site was located in the Dadu River valley, the soil was sandy gravel newly accumulated soil, about 850 meters above sea level, the climate belongs to the mid-latitude subtropical monsoon climate as the base zone mountain climate, the annual rainfall was $801.3 \mathrm{~mm}$, the average annual temperature was $16.9{ }^{\circ} \mathrm{C}$. The annual sunshine hours was 1245.6 hours, the average frost-free period was 326 days, the 
annual evaporation was $1573 \mathrm{~mm}$, the hottest month was August, the average temperature was $24.7^{\circ} \mathrm{C}$, the coldest month was January, the average temperature was $8{ }^{\circ} \mathrm{C}$.

\subsection{Experimental design}

The experimental site was flat and the soil type was the same. The row spacing of the tested yellow fruit citrus plant was $3 \times 4 \mathrm{~m}$. The experimental fertilization was divided into conventional fertilization and inoculation fertilization. Conventional fertilization was applied according to the fertilization habits of Huangguo mandarin growers. The fertilization time was March 5 and August 21, and each tree was treated with "Bao Shiling" inorganic-organic compound fertilizer $1.5 \mathrm{~kg}$. The treatment of inoculation and fertilization was as follows: the experimental design was a completely random design, a total of 4 treatments, with conventional fertilization as the control, each treatment was repeated 3 times. The purpose of bacterial fertilizer soil application was to inoculate the soil with Bacillus megaterium and Bacillus glia, only once, in the dense area of fibrous roots of the tree, and the application time was April 10. In conventional fertilization, $1.5 \mathrm{~kg}$ inorganic-organic compound fertilizer was applied to each tree, and the organic fertilizer was dried chicken manure. The treatment of each tree was shown in the table below.

Table 2. Inoculation and fertilization treatment

\begin{tabular}{|c|l|}
\hline Management & \multicolumn{1}{|c|}{ Internal capacity } \\
\hline $\mathrm{T} 1$ & $\begin{array}{l}\text { Application of Bacillus megaterium } \\
\text { fertilizer 250 } \mathrm{ml} \text { and conventional } \\
\text { fertilization }\end{array}$ \\
\hline $\mathrm{T} 2$ & $\begin{array}{l}\text { Application of Bacillus glia fertilizer 250 } \\
\text { ml and conventional fertilization }\end{array}$ \\
\hline $\mathrm{T} 3$ & $\begin{array}{l}\text { Application of 250 ml and conventional } \\
\text { fertilization for Bacillus megaterium and } \\
\text { Bacillus glia }\end{array}$ \\
\hline $\mathrm{T} 4$ & $\begin{array}{l}\text { Apply 250 ml of Bacillus megaterium, } \\
\text { 250 kg of Bacillus glia and 1.5 kg of } \\
\text { organic fertilizer. }\end{array}$ \\
\hline $\mathrm{CK}$ & Conventional fertilization \\
\hline
\end{tabular}

Note: the amount of bacterial fertilizer per tree $250 \mathrm{ml}$ refers to that of Aimin Zhang [3] and Changbin Luo [4].

\subsection{Experimental methods}

\subsubsection{Sample collection}

Referring to the method of Yunling Li [5], three key phenological periods of Huangguo mandarin were selected in the period of soil sampling, which were carried out in the period of physiological fruit drop, rapid expansion and fruit ripening, respectively, the specific time was June 15, August 20 and March 20. The sampling method was three-point sampling under the crown dripping line, and the soil depth was $0-40 \mathrm{~cm}$. The collected soil is naturally air-dried in a ventilated and dry place, ground and screened to be tested.

\subsubsection{Data analysis}

SPSS version19.0 was used to analyze the variance of the data, and Duncan's new complex difference method was used for multiple comparison, and the chart was drawn by Excel 2010.

\subsubsection{Determination of soil physical and chemical indexes}

Soil organic matter was determined by potassium dichromate volumetric method, soil alkali hydrolyzable nitrogen was determined by alkali hydrolysis diffusion method, total $\mathrm{P}$ was determined by $\mathrm{HClO}_{4}-\mathrm{H}_{2} \mathrm{SO}_{4}$ digestion method, available $\mathrm{P}$ was determined by $\mathrm{NH}_{4} \mathrm{~F}$ $\mathrm{HCl}$ extraction method, total $\mathrm{K}$ was determined by $\mathrm{NaOH}$ melting and flame photometry, and available $\mathrm{K}$ was determined by $\mathrm{NH}_{4} \mathrm{OAc}$ extraction and flame photometry [6].

\section{Results}

\subsection{Effect of phosphorus and potassium bacterial fertilizer on soil physical and chemical properties}

\subsubsection{Effect of phosphorus and potassium bacterial fertilizer on soil nutrients during physiological fruit drop period}

After applying bacterial fertilizer, the results of soil determination during physiological fruit drop period (Table 3) showed that T3 and T4 treatments were the best, which were significantly or very significantly higher than CK. There was no significant difference in organic matter, total $\mathrm{P}$ and total $\mathrm{K}$ between $\mathrm{T} 3$ and $\mathrm{T} 4$ treatments, but in alkali hydrolyzable nitrogen, available $\mathrm{P}$ and available $\mathrm{K}$, the values of $\mathrm{T} 4$ treatments were significantly higher than those of $\mathrm{T} 3$ penny $\mathrm{T} 1$ and $\mathrm{T} 2$ treatments, but higher than that of CK. In terms of single index, there were significant differences in alkalihydrolyzable nitrogen, total $\mathrm{P}$, available $\mathrm{P}$ and available $\mathrm{K}$ between the treatments and the control.

Table 3. Effect of phosphorus and potassium bacterial fertilizer on soil nutrients during physiological fruit drop period.

\begin{tabular}{|c|c|c|c|c|c|c|}
\hline Treatment & $\begin{array}{l}\text { Organic } \\
\text { matter/\% }\end{array}$ & $\begin{array}{c}\text { Alkali- } \\
\text { hydrolyzable } \\
\text { nitrogen/ } \\
\text { mg• } \mathrm{kg}^{-1}\end{array}$ & $\begin{array}{c}\text { Total } \\
\mathrm{P} / \mathrm{g}^{\circ} \mathrm{kg}^{-1}\end{array}$ & $\begin{array}{l}\text { Available } \\
\mathrm{P} / \mathrm{mg} \cdot \mathrm{kg}^{-1}\end{array}$ & $\begin{array}{l}\text { Full K } \\
/ \mathrm{g} \cdot \mathrm{kg}^{-1}\end{array}$ & $\begin{array}{l}\text { Available } \\
\mathrm{K} / \mathrm{mg} \mathrm{kg}^{-1}\end{array}$ \\
\hline
\end{tabular}




\begin{tabular}{|c|c|c|c|c|c|c|}
\hline T1 & $2.669 \mathrm{a}$ & $123.015 \mathrm{c}$ & $0.190 \mathrm{~b}$ & $22.076 \mathrm{c}$ & $12.115 \mathrm{ab}$ & $216.726 \mathrm{c}$ \\
\hline $\mathrm{T} 2$ & $2.711 \mathrm{a}$ & $136.498 \mathrm{~b}$ & $0.157 \mathrm{c}$ & $20.840 \mathrm{c}$ & $12.671 \mathrm{ab}$ & $220.890 \mathrm{c}$ \\
\hline $\mathrm{T} 3$ & $2.822 \mathrm{a}$ & $142.251 \mathrm{~b}$ & $0.211 \mathrm{a}$ & $24.388 \mathrm{~b}$ & $14.450 \mathrm{a}$ & $257.483 \mathrm{~b}$ \\
\hline $\mathrm{T} 4$ & $3.029 \mathrm{a}$ & $157.547 \mathrm{a}$ & $0.218 \mathrm{a}$ & $27.205 \mathrm{a}$ & $14.191 \mathrm{a}$ & $298.429 \mathrm{a}$ \\
\hline $\mathrm{CK}$ & $1.997 \mathrm{~b}$ & $122.461 \mathrm{c}$ & $0.148 \mathrm{c}$ & $17.979 \mathrm{~d}$ & $11.523 \mathrm{~b}$ & $203.893 \mathrm{c}$ \\
\hline
\end{tabular}

Note: $a, b, c$ indicate the results of Duncan test at 0.05 and 0.01 level at the same column. The same below.

\subsubsection{Effect of phosphorus and potassium bacterial fertilizer on soil nutrients during rapid expansion period}

The results of soil determination during the rapid expansion period (Table 4) showed that T3 and T4 treatments were the best, which were significantly or very significantly higher than $\mathrm{CK}$. There was no significant difference between $\mathrm{T} 3$ and $\mathrm{T} 4$ treatments in organic matter, total $\mathrm{P}$ and total $\mathrm{K}$, but in alkali hydrolyzable nitrogen, available $\mathrm{P}$ and available $\mathrm{K}$, T4 treatment was significantly higher than $\mathrm{T} 3$, which increased by $9.95 \%, 20.73 \%$ and $20.81 \%$, respectively. As for a single index, the contents of organic matter, alkali-hydrolyzable nitrogen, total $\mathrm{P}$, available $\mathrm{P}$ and available $\mathrm{K}$ in each treatment were significantly higher than those in $\mathrm{CK}$.

\subsubsection{Effects of phosphorus and potassium bacterial Fertilizer on soil nutrients during Fruit ripening}

The results of soil determination during fruit ripening period (Table 5) showed that T3 and T4 treatments were the best, which were significantly or very significantly higher than CK. There was no significant difference between $\mathrm{T} 3$ and $\mathrm{T} 4$ in available $\mathrm{P}$, but in organic matter, alkali-hydrolyzable nitrogen, total $\mathrm{P}$, total $\mathrm{K}$ and available K, T4 was significantly higher than T3.

Table 4. Effect of phosphorus and potassium bacterial fertilizer on soil nutrients during rapid expansion period.

\begin{tabular}{|c|c|c|c|c|c|c|}
\hline Treatment & $\begin{array}{c}\text { Organic } \\
\text { matter/\% }\end{array}$ & $\begin{array}{c}\text { Alkali- } \\
\text { hydrolyzable } \\
\text { nitrogen/ } \\
\mathrm{mg} \bullet \mathrm{kg}^{-1}\end{array}$ & $\begin{array}{c}\text { Total } \\
\mathrm{P} / \mathrm{g}^{\circ} \mathrm{kg}^{-1}\end{array}$ & $\begin{array}{c}\text { Available } \\
\mathrm{P} / \mathrm{mg}^{\circ} \mathrm{kg}^{-1}\end{array}$ & $\begin{array}{c}\text { Full K } \\
/ \mathrm{g}^{\circ} \mathrm{kg}^{-1}\end{array}$ & $\begin{array}{c}\text { Available } \\
\mathrm{K} / \mathrm{mg}^{-1} \mathrm{~kg}^{-1}\end{array}$ \\
\hline $\mathrm{T} 1$ & $2.815 \mathrm{~b}$ & $129.967 \mathrm{~d}$ & $0.220 \mathrm{~b}$ & $25.043 \mathrm{c}$ & $13.175 \mathrm{a}$ & $239.648 \mathrm{c}$ \\
\hline $\mathrm{T} 2$ & $2.786 \mathrm{~b}$ & $137.619 \mathrm{c}$ & $0.213 \mathrm{~b}$ & $24.041 \mathrm{c}$ & $13.184 \mathrm{a}$ & $240.761 \mathrm{c}$ \\
\hline $\mathrm{T} 3$ & $3.259 \mathrm{a}$ & $152.159 \mathrm{~b}$ & $0.229 \mathrm{ab}$ & $26.763 \mathrm{~b}$ & $13.139 \mathrm{a}$ & $263.962 \mathrm{~b}$ \\
\hline $\mathrm{T} 4$ & $3.299 \mathrm{a}$ & $167.293 \mathrm{a}$ & $0.243 \mathrm{a}$ & $32.311 \mathrm{a}$ & $13.595 \mathrm{a}$ & $318.889 \mathrm{a}$ \\
\hline $\mathrm{CK}$ & $2.629 \mathrm{c}$ & $120.580 \mathrm{e}$ & $0.170 \mathrm{c}$ & $22.107 \mathrm{~d}$ & $12.477 \mathrm{~b}$ & $233.240 \mathrm{c}$ \\
\hline
\end{tabular}

Table 5. Effects of phosphorus and potassium bacterial fertilizer on soil nutrients during fruit ripening

\begin{tabular}{|c|c|c|c|c|c|c|}
\hline Treatment & $\begin{array}{c}\text { Organic } \\
\text { matter/\% }\end{array}$ & $\begin{array}{c}\text { Alkali- } \\
\text { hydrolyzable } \\
\text { nitrogen/ } \\
\mathrm{mg} \cdot \mathrm{kg}^{-1}\end{array}$ & $\begin{array}{c}\text { Total } \\
\mathrm{P} / \mathrm{g} \bullet \mathrm{kg}^{-1}\end{array}$ & $\begin{array}{c}\text { Available } \\
\mathrm{P} / \mathrm{mg}^{\circ} \mathrm{kg}^{-1}\end{array}$ & $\begin{array}{c}\text { Full K } \\
/ \mathrm{g}^{-1} \mathrm{~kg}^{-1}\end{array}$ & $\begin{array}{c}\text { Available } \\
\mathrm{K} / \mathrm{mg}^{-1} \mathrm{~kg}^{-1}\end{array}$ \\
\hline $\mathrm{T} 1$ & $2.490 \mathrm{c}$ & $114.282 \mathrm{c}$ & $0.197 \mathrm{c}$ & $24.891 \mathrm{ab}$ & $12.691 \mathrm{~b}$ & $192.755 \mathrm{C}$ \\
\hline $\mathrm{T} 2$ & $2.392 \mathrm{~cd}$ & $113.978 \mathrm{c}$ & $0.193 \mathrm{c}$ & $24.359 \mathrm{ab}$ & $12.949 \mathrm{ab}$ & $193.166 \mathrm{C}$ \\
\hline $\mathrm{T} 3$ & $2.790 \mathrm{~b}$ & $149.832 \mathrm{~b}$ & $0.213 \mathrm{~b}$ & $25.022 \mathrm{ab}$ & $12.407 \mathrm{~b}$ & $209.563 \mathrm{~b}$ \\
\hline $\mathrm{T} 4$ & $3.124 \mathrm{a}$ & $167.293 \mathrm{a}$ & $0.245 \mathrm{a}$ & $25.617 \mathrm{a}$ & $13.366 \mathrm{a}$ & $224.215 \mathrm{a}$ \\
\hline $\mathrm{CK}$ & $2.260 \mathrm{~d}$ & $112.770 \mathrm{c}$ & $0.159 \mathrm{~d}$ & $22.436 \mathrm{~b}$ & $13.032 \mathrm{ab}$ & $177.591 \mathrm{~d}$ \\
\hline
\end{tabular}

\section{Discussion and Conclusion}

Based on the above test results, the different indexes of different treatments in the same period were higher than that of CK, among which T3 and T4 treatments were the best, indicating that there was a synergistic effect between Bacillus megaterium and Bacillus glia, and it was suggested that T4 treatment was better than T3 treatment, and it was suggested that organic manure with more bacteria should be applied at the same time. Among them, the index of the optimal treatment is much 
higher than that of the control, which is consistent with the research conclusion of Yalian Zhang[7] and Zhihui Gou[8]. Biological bacterial fertilizer can effectively improve the content of soil nutrients.

To sum up, the treatment effect of applying Bacillus megaterium, Bacillus glia and organic fertilizer is the best, which can significantly increase the content of soil nutrients. Secondly, the treatment effect of applying Bacillus megaterium, Bacillus glia and "Bao Shi Ling" inorganic-organic compound fertilizer is better, which reaches a significant level in many indexes, which is better than other treatments. In addition, the treatment of applying Bacillus megaterium and Bacillus gelatinosa alone reached a significant level in many soil nutrient indexes, and the combination of Bacillus megaterium, Bacillus glia and organic fertilizer was suggested in production.

\section{Acknowledgments}

This study was completed independently by myself under the strict requirements and careful guidance of my tutor, teacher Bo Xiong. I have benefited a lot from my tutor's rigorous academic attitude and earnest and sincere attitude. I would like to express my deep respect to my mentor Finally, once again, I would like to thank all the mentors and classmates who have helped me in the process of writing my graduation thesis, as well as the authors who have been quoted or referenced by me in the thesis.

\section{References}

1. Z.Q., Zhang, D.H., Wang. (1994) Study on the genetic relationship of Huangguo mandarin by isozyme analysis. J. Journal of Sichuan Agricultural University., 12 (1): 81-83.

2. Sichuan Academy of Agricultural Sciences. (1975) Horticulture experimental station. Atlas of improved varieties of fruit trees in Sichuan. M. Beijing: Beijing Agricultural Publishing House.,42-43.

3. A.M., Zhang, S.F., Zhang, G.Y., Zhao, B.C., Zhu, S.N., Li.(2013) Development of fertilizer preparation of Bacillus glia strain $C X-9$ and its application in tobacco. J. Journal of Hebei University: natural Science Edition, Journal.,33 (4): 387-393.

4. C.B., Chu, S.H., Wu, X.Y., Zhang, D.P., Zhou, J.Q., Fan, Z.F., Jiang. (2011) Effects of microbial fertilizer on soil fertility, citrus nutrients and quality in citrus orchard. J. Shanghai Agricultural Science and Technology.,11(1): 93-94.

5. Y.L., Li. (2004) Study on the application effect of biological bacterial fertilizer under different soil moisture conditions.D. Shanxi: Shanxi Agricultural University.

6. S.D., Bao. (2000) Soil agrochemical analysis (third edition). M. Beijing: China Agricultural Publishing House. ,12.
7. Y.L., Zhang, S.Q., Chang, H.Y., Liu, H.P., Fu, J.Q., Li. (2008) Study on nutritional effect of Biobacterial Fertilizer in Tea Garden. J. Tea Science.,28 (2): 123-128.

8. Z.H., Gou. (2010) Study on combination Optimization and bacterial Fertilizer of functional strains in Rhizosphere of Camellia oleifera. D. Changsha, Hunan: college of Forestry, Central South University of Forestry Science and Technology. 